\title{
KAJIAN HAK ASASI MANUSIA DALAM NEGARA THE RULE OF LAW: ANTARA HUKUM PROGRESIF DAN HUKUM POSITIF
}

\author{
Mukhamad Luthfan Setiaji \\ Mahasiswa Fakultas Hukum, Universitas \\ Negeri Semarang \\ Surel: luthfansetiaji@gmail.com
}

\author{
Aminullah Ibrahim \\ Mahasiswa Fakultas Hukum, Universitas \\ Negeri Semarang \\ Surel: aminullah.ibrahum03@gmail.com
}

\begin{abstract}
ABSTRAK
Pembentukan hukum tidak lepas dari putusan-putusan hakim (judge made law) yang terkait dengan penegakan hukum, sedangkan penegakan hukum pada hakikatnya adalah merupakan suatu proses untuk mewujudkan tujuantujuan hukum ide-ide hukum menjadi kenyataan. Tulisan ini mengkaji tentang aspek-aspek hak asasi manusia dalam negara hukum, antara hukum progresif dan hukum positif. Hukum Progresif adalah hukum pro keadilan dan pro rakyat , artinya dalam berhukum para pelaku hukum dituntut mengedepankan kejujuran, empati, kepedulian kepada rakyat dan ketulusan dalam penegakan hukum.
\end{abstract}

RIWAYAT ARTIKEL

Article History

Diterima 25 April 2017

Dipublikasi 20 November 2018

\section{KATA KUNCI}

Keywords

Hak Asasi Manusia (HAM), Hukum

Progresif, Negara The Rule of Law,

\section{HOW TO CITE (saran perujukan):}

Setiaji, M.L. \& Ibrahim, A. (2018). "Kajian Hak Asasi Manusia dalam Negara The Rule of Law. Antara Hukum Progresif dan Hukum Positif", Lex Scientia Law Review. Volume 2 No. 2, November, hlm. 123-138 


\section{PENDAHULUAN}

Dari perjalanan waktu lembaga peradilan di Indonesia mengalami perubahan-perubahan seiring dengan perkembangan zaman, baik dari kelembagaannya maupun dalam sistem penegakan hukumnya (Mujahidin,2007:64). Pengertian penegakan hukum dalam arti luas yaitu meliputi pelaksanaan dan penerapan hukum terhadap setiap pelanggaran atau penyimpangan hukum yang dilakukan oleh subjek hukum, serta dalam arti sempit merupakan kegiatan penindakan terhadap setiap pelanggaran atau penyimpangan terhadap peraturan perundang-undangan (Utsman,2008: 30). Penegakan hukum di Indonesia pasca reformasi dapat dikatakan gagal karena masih miskinnya implementasi terhadap nilai-nilai moral dan akan berjarak serta terisolasi dari masyarakatnya terutama mengenai masalah Hak Asasi Manusia (HAM). Hak asasi memberikan kekuatan moral untuk menjamin dan melindungi martabat menusia berdasarkan hukum, bukan atas dasar kehendak, keadaan, ataupun kecenderungan politik tertentu (Lisanawati, 2014: 5).

Deklarasi Hak-hak Asasi Manusia bagi negara Indonesia telah ada dari jaman dahulu namun baru di ikrarkan pada pedoman dasar negara ini yaitu yang berada di dalam pembukaan Undang- Undang Dasar 1945 yang di dalamnya terdapat hak- hak asasi selaku manusia baik manusia selaku mahluk pribadi maupun sebagai mahluk sosial yang di dalam kehidupannya itu semua menjadi sesuatu yang inheren, serta dipertegas dalam Pancasila dari sila pertama hingga sila kelima, Jika dilihat dari terbentuknya deklarasi Hak Asasi Manusia bangsa Indonesia lebih dahulu terbentuk dari pada Hak-Hak Asasi Manusia PBB yang baru terbentuk pada tahun 1948 (Supriyanto,2014). Dalam Undang-Undang No. 39 Tahun 1999 tentang Hak Asasi Manusia, pengaturan mengenai hak asasi manusia ditentukan dengan berpedoman pada Deklarasi Hak Asasi Manusia Perserikatan Bangsa-Bangsa, Konvensi Perserikatan Bangsa- Bangsa tentang Penghapusan Segala Bentuk Diskriminasi terhadap Wanita, Konvensi Perserikatan Bangsa-bangsa tentang Hak-hak Anak, dan berbagai instrument internasional lain yang mengatur mengenai hak asasi manusia. Materi Undang-Undang ini disesuaikan juga dengan kebutuhan hukum masyarakat dan pembangunan hukum nasional yang berdasarkan Pancasila dan UndangUndang Dasar 1945. Sedangkan di dalam Undang-Undang Dasar 1945 (yang diamandemen), masalah mengenai HAM dicantumkan secara khusus dalam Bab X Pasal 28 A sampai dengan $28 \mathrm{~J}$, yang merupakan hasil Amandemen Kedua Tahun 2000.

Di mancanegara dan Indonesia khususnya, tercatat banyak kasus pelanggaran Hak Asasi Manusia (HAM) atau kejahatan atas kemanusiaan, dimana pelakunya bebas berkeliaran dan bahkan tak terjangkau oleh hukum atau dengan kata lain perkataan membiarkan tanpa penghukuman oleh negara terhadap pelakunya impunity.Impunitas yaitu membiarkan para pemimpin politik dan militer

https://journal.unnes.ac.id/sju/index.php//sir/

Copyrights (C) 2018. UKM Lex Scientia, Fakultas Hukum Universitas Negeri Semarang 
yang diduga terlibat dalam kasus pelanggaran berat Hak Asasi Manusia seperti, kejahatan genosida, kejahatan manusia, dan kejahatan perang tidak diadili merupakan fenomena hukum politik yang dapat kita saksikan sejak abad yang lalu hingga hari ini (Nusantara,2004). Studi terhadap positivisme hukum di Indonesia menjadi sangat penting saat ini di saat bangsa ini sedang dan selalu terus membangun peradabannya ke ranah yang sesuai dengan rasa keadilan masyarakat. Positivisme telah melahirkan hukum dalam sketsa matematika, menyelesaikan hukum yang terjadi di masyarakat berdasar apa yang tertulis dalam undang-undang, mengkristal di posisi binernya lalu pembaca harus memahami di keadaan itu dan tidak dibolehkan untuk berpikir lain (Sarmadi,2012: 331). Sementara para hakim memutus perkara dengan teks tersebut atas persoalan hukum yang dihadapi. Keadilan dipelihara oleh peraturan hukum, menegakkan kebebasan manusia fundamental, sama dan tidak dapat dicabut hak yang setiap manusia terlahir adalah kondisi penting kita. Untuk Mencapai ini untuk mempromosikan dan melindungi kepentingan sipil, politik, ekonomi, hak asasi manusia sosial dan budaya setiap wanita, pria dan anak (Prince Zeid Ra'ad,2017: 242).

Seperti halnya di Indonesia, hakim memutus perkara mengutamakan hukum tertulis sebagai sumber utamanya, kelompok-kelompok hakim yang berpikir demikian dapat digolongkan sebagai aliran konservatif (Siahaan,2006: 35). Produk hukum sendiri akan menghasilkan formalistik dimana kepastian hukum menjadi ikon kebenaran. Keadilan adalah keadilan yang terdefinisi atas apa yang tertulis dan menutup diri atas keadilan yang selama ini tidak termaktub dalam suatu teks perundang-undangan. Teori ini mengidentikkan hukum dengan undang-undang, yaitu tidak ada hukum di luar undang-undang dan satu-satunya hukum adalah undang-undang (Muhammad,2006:222-223). Pemikiran Hukum Progresif muncul karena ketidakpuasan dan keprihatinan terhadap kinerja dan kualitas penegakan hukum yang ada dalam masyarakat.

Hukum Progresif adalah hukum pro keadilan dan pro rakyat, artinya dalam berhukum para pelaku hukum dituntut mengedepankan kejujuran, empati, kepedulian kepada rakyat dan ketulusan dalam penegakan hokum (Tanya,2010: 212). Pembentukan hukum dan konstruksi hukum sangat diperlukan untuk dapat memberikan rasa nyaman terhadap masyarakat sebagai akses untuk keadilan. Pembentukan hukum tidak lepas dari putusan-putusan hakim (judge made law) yang terkait dengan penegakan hukum, sedangkan penegakan hukum pada hakikatnya adalah merupakan suatu proses untuk mewujudkan tujuan-tujuan hukum ide-ide hukum menjadi kenyataan (Esmi,2005: 11). Penegakan hukum konvensional tidak selalu dapat mewujudkan nilai keadilan masyarakat, maka perlu ada kontruksi penegakan hukum progresif yang dapat mewujudkan nilai keadilan yang berorientasi pada kesejahteraan dan perlindungan terhadap Hak Asasi Manusia. Ide penegakan hukum progresif lahir dari ketidakpuasan pada praktik ajaran ilmu hukum positif di Indonesia. Hukum progresif digagas sebagai solusi dari kegagalan penerapan hukum 
positif dan rasa keprihatinan terhadap kualitas penegakan hukum di Indonesia terutama sejak terjadinya reformasi pada pertengahan tahun 1998. Hukum tidak hadir untuk dirinya sendiri sebagaimana yang digagas oleh hukum positif, melainkan untuk manusia dalam rangka mencapai kesejahteraan dan kebahagiaan manusia. Progresivisme tidak ingin menjadikan hukum sebagai teknologi yang tidak bernurani, melakukan suatu institusi yang bermoral kemanusiaan(Rahardjo,2009: 53).

\section{Rumusan Masalah}

1. Bagaimana kajian Hak Asasi Manusia dalam perspektif hukum positif?

2. Bagaimana kajian Hak Asasi Manusia dalam perspektif hukum progresif?

\section{Metode Penulisan}

1. Pengumpulan Data

Metode Studi pustaka, dimana pengumpulan informasi yang dibutuhkan dilakukan dengan mencari referensi-referensi yang berhubungan dengan penelitian yang dilakukan, referensi dapat diperoleh dari buku-buku, jurnal-jurnal atau internet.

2. Sumber Data

Sumber Data Sekunder, diperoleh dari buku-buku literatur dan jurnal ilmiah.

\section{PEMBAHASAN}

\section{A. Hak Asasi Manusia dalam Perspektif Hukum Progresif}

Penegakan hukum progresif adalah menjalankan hukum tidak sekedar menurut kata-kata hitam-putih perundangan, melainkan menurut semangat dan makna lebih dalam dari undang-undang atau hukum (Rahardjo,2006: 6). Penerapan hukum progresif, mengarahkan hukum yang dihasilkan oleh proses legislasi, yang cenderung elitis, untuk mengarah pada kepentingan keadilan dan kesejahteraan rakyat banyak pintu masuk bagi penerapan hukum progresif dalam praktik pengadilan di Indonesia, secara formal telah diberikan oleh Undang-Undang Nomor 48 Tahun 2009 tentang Kekuasaan Kehakiman yang menegaskan bahwa kekuasaan kehakiman bertugas untuk menegakkan hukum dan keadilan. Hukum progresif berbeda dengan hukum positif. Progresifisme hukum mengajarkan bahwa hukum bukan raja, tetapi alat untuk menjabarkan dasar kemanusiaan yang berfungsi memberikan rahmat kepada dunia dan manusia. Asumsi yang mendasari progresifisme hukum adalah pertama hukum ada untuk manusia dan tidak untuk dirinya sendiri, kedua hukum selalu berada pada status law in the making dan tidak bersifat final, ketiga hukum adalah institusi yang bermoral kemanusiaan. 
Berdasar asumsi-asumsi di atas maka kriteria hukum progresif adalah:

a. Mempunyai tujuan besar berupa kesejahteraan dan kebahagiaan manusia.

b. Memuat kandungan moral kemanusiaan yang sangat kuat.

c. Hukum progresif adalah hukum yang membebaskan dimensi yang amat luas yang tidak hanya bergerak pada ranah praktik melainkan juga teori.

d. Bersifat kritis dan fungsional (Rahardjo,2006: 6).

Konsep hukum progresif yang dikemukakan oleh Satjipto Rahardjo bilamana diartikan secara sederhana berarti "bagaimana" membiarkan hukum tersebut mengalir untuk menuntaskan tugasnya mengabdi pada manusia dan kemanusiaan. Adapun pokok-pokok pemikiran model hukum progresif ini dapat diuraikan sebagai berikut :

1. Hukum menolak tradisi analytical jurisprudence atau rechtsdogmatick dan berbagi paham dengan aliran seperti legal realism, freirechtslehre, sosiological jurisprudence, interressenjurisprudenz di Jerman, teori hukum alam dan critical legal studies.

2. Hukum menolak pendapat, bahwa ketertiban (order), hanya bekerja melalui institusi-institusi kenegaraan.

3. Hukum progresif ditujukan untuk melindungi rakyat menuju kepada ideal hukum.

4. Hukum menolak status-quo serta tidak ingin menjadikan hukum sebagai teknologi yang tidak bernurani, melainkan suatu institusi yang bermoral.

5. Hukum adalah suatu institusi yang bertujuan mengantarkan manusia kepada kehidupan yang adil, sejahtera dan membuat manusia bahagia.

6. Hukum progresif adalah "hukum yang pro rakyat" dan " hukum yang pro keadilan".

7. Asumsi dasar hukum progresif adalah, bahwa "hukum adalah untuk manusia", bukan sebaliknya. Berkaitan dengan hal tersebut, maka hukum tidak ada untuk dirinya sendiri, melainkan untuk sesuatu yang lebih luas dan lebih besar. Maka setiap kali ada masalah dalam dan dengan hukum, hukumlah yang ditinjau dan diperbaiki, bukan manusia yang dipaksakan untuk dimasukkan ke dalam sistem hukum.

8. Hukum bukan merupakan suatu institusi yang absolut dan final melainkan sangat bergantung pada bagaimana manusia melihat dan menggunakannya. Manusialah yang merupakan penentu.

9. Hukum selalu berada dalam proses untuk terus menjadi (law as a process, law in the making) (Atmasasmita,2012: 88-89). 
Satjipto Rahardjo secara tegas menyampaikan hukum progresif menolak tradisi analytical yurisprudensi atau rechdogmateik, dan berbagai paham dengan aliran legal realism, freirechtslehre, sociological jurisprudensi, interesenjurisprudenze, teori hukum alam dancritical legal studies. Hukum progresif merupakan koreksi terhadap kelemahan system hukum modern yang sarat dengan birokrasi serta ingin membebaskan diri dari dominasi suatu tipe hukum liberal (Rahardjo,2006: 1).

Ide utama dari hukum progresif adalah membebaskan manusia dari belenggu hukum. Hukum berfungsi memberi panduan bukan justru membelenggu, manusiamanusialah yang lebih penting. Hukum hendaknya mampu mengikuti perkembangan zaman, mampu menjawab dengan segala dasar di dalamnya, serta mampu melayani masyarakat dengan menyandarkan pada aspek moralitas dari sumber daya manusia penegak hukum itu sendiri (Rahardjo,2006: 1). Asas praduga tak bersalah terdapat ketentuannya dalam KUHAP dan Undang-Undang No. 48 Tahun 2009 tentang Kekuasaan Kehakiman. Dalam KUHAP terdapat ketentuannya pada butir tiga bagian $\mathrm{C}$ yang rumusannya sebagai berikut:

"Setiap orang yang disangka, ditangkap, ditahan, dituntut dan atau dihadapkan di muka sidang pengadilan, wajib dianggap tidak bersalah sampai adanya putusan pengadilan yang menyatakan kesalahannya dan memperoleh kekuatan hukum tetap."

Berdasarkan dari ketentuan KUHAP dan Undang-Undang No. 48 Tahun 2009 maka dapat disimpulkan bahwa setiap orang yang masih disangka san belum ada putusan pengadilan maka dianggap tidak bersalah sampai adanya kekuatan hukum tetap. Asas praduga tak bersalah secara tersirat juga terdapat dalam didalam ketentuan Magna Charta 1215 yang dianggap sebagai cikal bakal lahirnya HAM dilingkup internasional. Menurut Living Stone Half, Pasal 39 dalam Magna Charta menentukan bahwa:

"Tidak seorangpun boleh dikurung dirampas miliknya, dikucilkan atau diambil nyawanya, kecuali melalui hukuman yang sah oleh negaranya." (Rukmini,2007: 42)

Hak-hak tersangka dijamin dan dilindungi oleh undang-undang dalam proses penanganan perkara pidana, hal ini mnunjukan bahwa KUHAP menghormati dan menjunjung tinggi harkat dan martabat manusia dengan memberikan perlindungan dan jaminan terhadap hak-hak asasi manusia (tersangka). Dengan demikian diperoleh jaminan bahwa tujuan akhir dari KUHAP yakni untuk menegaskan kebenaran dan keadilan secara konkrit dalam suatu perkara pidana (F.S, 2004: 82). Perlu disadari bahwa proses hukum yang adil tidak sekedar menerapkan peraturan perundang-undangan, namun lebih kepada sikap kita dalam menghargai hak-hak setiap individu (termasuk tersangka dan terdakwa) sebagaimana terkandung dalam 
UUD 1945 yang menyatakan bahwa "kemerdekaan ialah hak segala bangsa". Kita pun harus ingat bahwa diri kita, kita dapat mendisplinkan diri untuk tidak melakukan pelanggaran hukum, tetapi bukankah kita tidak dapat bebas dari risiko menjadi seorang "tersangka" kemudian pula "terdakwa?" disinilah letak pentingnya kita memperjuangkan tegaknya hak-hak tersangka/terdakwa untuk :

a. Didengar penjelasannya;

b. Didampingi oleh penasihat hukum;

c. Dibuktikan kesalahannya oleh penuntut umum;

d. Dan dihadapkan pada pengadilan yang adil dan tidak berpihak.

Pasal 27 ayat (1) berbunyi "segala warga negara bersamaan kedudukannya di dalam hukum dan pemerintahan dan wajib menjunjung hukum dan pemerintahan itu dengan tidak ada kecualinya". Ketentuan dalam UUD 1945 diatas, dapat ditemukan ketentuannya dalam peraturan perundang-undangan sebagai berikut:

a. Undang-Undang No. 48 Tahun 2009 tentang Kekuasaan Kehakiman Pasal 4 ayat (1) yang berbunyi: "pengadilan mengadili menurut hukum dengan tidak membeda-bedakan orang".

b. Undang-Undang No. 8 Tahun 1981 tentang Hukum Acara Pidana tersirat di dalam bagian menimbang huruf a yang berbunyi: "bahwa negara Republik Indonesia adalah negara hukum yang berdasarkan atas Pancasila dan UndangUndang Dasar 1945, yang menjunjung tinggi hak-hak asasi menusia serta yang menjamin segala warganegara bersamaan kedudukannya di dalam hukum dan pemerintahan dan wajib menjunjung hukum dan pemerintahan itu dengan tidak ada kecualinya", dan penjelasan umum butir 3 huruf a yang berbunyi: "perlakuan yang sama atas diri setiap orang di muka hukum dengan tidak mengadakan pembedaan perlakuan".

c. Undang-Undang No. 39 Tahun 1999 tentang HAM Pasal 3 ayat (2) yang berbunyi: "setiap orang berhak atas pengakuan, jaminan, perlindungan, dan perlakuan hukum yang adil serta mendapat kepastian hukum dan perlakuan yang sama di depan hukum", dan Pasal 5 ayat (1) yang berbunyi: "setiap orang diakui sebagai manusia pribadi yang berhak menuntut dan memperoleh perlakuan serta perlindungan yang sama sesuai dengan martabat kemanusiaannya di depan hukum".

d. Undang-Undang No. 26 Tahun 2000 tentang Pengadilan HAM, tersirat di dalam Pasal 10 yang berbunyi: "dalam hal tidak ditentukan lain dalam Undang-undang ini, hukum acara atas perkara pelanggaran hak asasi manusia yang berat dilakukan berdasarkan ketentuan hukum acara pidana". 
Di dalam KUHAP terdapat 7 (tujuh) asas umum dan 3 (tiga) asas khusus yaitu sebagai berikut:

a. Asas umum

1) Perlakuan yang sama dimuka hukum tanpa diskriminasi apapun;

2) Praduga tidak bersalah;

3) Hak untuk memperoleh kompensasi (ganti rugi) dan rehabilitasi;

4) Hak untuk mendapatkan bantuan hukum;

5) Hak kehadiran Terdakwa dimuka pengadilan;

6) Peradilan yang bebas dan dilakukan dengan cepat dan sederhana;

7) Peradilan yang terbuka untuk umum.

b. Asas khusus

1) Pelanggaran atas hak-hak individu (penangkapan, penggeledahan, penahanan dan penyitaan) harus didasarkan pada undang-undang dan dilakukan dengan surat perintah tertulis;

2) Hak seorang Tersangka untuk diberitahu tentang persangkaan dan pendakwaan terhadapnya;

3) Kewajiban pengadilan untuk mengendalikan pelaksanaan putusanputusannya (Reksodiputro: 32-33).

Setiap orang berhak memperoleh putusan yang adil dan tidak membedabedakan, dengan berdasarkan fakta-fakta yang terbukti dihadapan persidangan. Menurut Mardjono Reksodiputro, perlakuan yang sama di depan hukum tidak harus ditafsirkan terhadap Terdakwa yang berbeda kedudukan atau kekayaannya tetapi harus lebih dari itu. Oleh karena itu, disini adalah wajib dihindarinya diskriminasi berdasarkan : "race, sex, language, religion, national or social origin, property, borth or other status" (Reksodiputro: 154). KUHAP melihat peradilan dalam konteks hukum yang adil melalui asas praduga tak bersalah dan asas kesamaan kedudukan dihadapan hukum, dalam ketentuan di dalamnya telah termaktub tujuan menuju system hukum berbasis due preprocess law, namun tampaknya masih saja banyak penyelewengan kedua asas tersebut. Indonesia benar adalah negara hukum yang menjunjung tinggi hak-hak manusia sesuai dengan pertimbangan pertama dalam Undang-Undang Nomor 8 Tahun 1981 tentang Hukum Acara Pidana yang berbunyi: "bahwa negara Republik Indonesia adalah negara hukum yang berdasarkan atas Pancasila dan Undang-Undang Dasar 1945, yang menjunjung tinggi hak-hak asasi menusia serta yang menjamin segala warganegara bersamaan kedudukannya di dalam hukum dan pemerintahan dan wajib menjunjung hukum dan pemerintahan itu dengan tidak ada kecualinya". 


\section{B. Hak Asasi Manusia dalam Perspektif Hukum Positif}

Dalam kaca mata aliran hukum positif, tiada hukum lain kecuali perintah penguasa atau inti aliran hukum positif ini menyatakan bahwa norma hukum adalah sah apabila ia ditetapkan oleh lembaga atau otoritas yang berwenang dan didasarkan pada aturan yang lebih tinggi, bukan digantungkan pada nilai moral. Norma hukum yang ditetapkan itu tidak lain adalah Undang-undang. Undang-Undang adalah sumber hukum, di luar Undang-undang bukan hukum. Teori hukum positif mengakui adanya norma hukum yang bertentangan dengan nilai moral, tetapi hal ini tidak mengurangi keabsahan norma hukm tersebut (Erwin,2012: 154).

Sebagai cermin dari kesungguhan negara Indonesia dalam menghormati, melindungi, dan memajukan HAM bagi warganegaranya, kemudian disahkan sejumlah UU seperti:

a. UU No. 8/1999 tentang Kebebasan Menyatakan Pendapat;

b. UU No. 39/1999 tentang HAM;

c. UU No. 26/2000 tentang Pengadilan HAM;

d. Amandemen berbagai UU untuk diselaraskan dengan prinsip-prinsip HAM, seperti UU Parpol, UU Kekuasaan Kehakiman, pencabutan Penpres No. $11 / 1963$, dsb.

e. Diluncurkan Rencana Aksi Nasional HAM (RAN-HAM) dalam rangka memberikan jaminan bagi peningkatan pemajuan dan perlindungan HAM di Indonesia dengan mempertimbangkan nilai-nilai adat istiadat, budaya, dan agama bangsa Indonesia yang berdasarkan Pancasila dan UUD Tahun 1945 (Ibrahim,2010: 6).

Secara normatif, hal yang cukup menggembirakan dalam perlindungan HAM di Indonesia adalah diterbitkannya UU No. 39/1999 tentang HAM dan UU No. 26/2000 tentang Pengadilan HAM. Menurut Penjelasan Umum UU No. 39/1999, posisi hukum UU tersebut "adalah merupakan payung dari seluruh peraturan perundang-undangan tentang HAM. Oleh karena itu, pelanggaran baik langsung maupun tidak langsung atas HAM dikenakan sanksi pidana, perdata, dan atau administratif sesuai dengan ketentuan peraturan perundang-undangan". UU No. 39/1999 secara rinci mengatur tentang: hak untuk hidup dan hak untuk tidak dihilangkan paksa dan/atau tidak dihilangkan nyawa, hak berkeluarga dan melanjutkan keturunan, hak mengembangkan diri, hak memperoleh keadilan, hak mengembangkan diri, hak memperoleh keadilan, hak atas kebebasan pribadi, hak atas rasa aman, hak atas kesejahteraan, hak turut serta dalam pemerintahan, hak wanita, hak anak, dan hak atas kebebasan beragama. Semua hak itu terumus dalam Bab III di bawah judul HAM dan Kebebasan Dasar Manusia (Pasal 9 - Pasal 66) (Ibrahim,2010: 6).

UU No. 39/1999 juga mengatur tentang Kewajiban Dasar Manusia. Dalam Pasal 69 ayat (2) dirumuskan bahwa: "Setiap HAM seseorang menimbulkan 
kewajiban dasar dan tanggung jawab untuk menghormati HAM orang lain secara timbal balik serta menjadi tugas Pemerintah untuk menghormati, melindungi, menegakkan, dan memajukannya". Bahkan dalam Pasal 71 disebutkan bahwa masalah itu bukan hanya tugas pemerintah saja, namun pemerintah wajib dan bertanggung jawab menghormati, melindungi, menegakkan dan memajukan HAM. Di samping perkembangan HAM dalam instrumen hukum nasional yang menggembirakan tersebut, dalam catatan ELSAM ada ironi terkait dengan legislasi HAM di tingkat daerah. ELSAM mencatat, otonomi daerah berdasarkan UU No 22/1999 yang telah diganti dengan UU No 32 /2004 ternyata berdampak banyaknya produk hukum daerah, terutama Peraturan Daerah (Perda) dianggap bermasalah. Oleh karena itu, Perda-Perda yang demikian itu perlu ada perhatian tersendiri mengingat Perda merupakan satu kesatuan yang tidak bias dilepaskan dari sistem peraturan perundang-undang Indonesia (Ibrahim,2010: 6-7).

Pengaturan mengenai Hak Asasi Manusia telah ada sejak di sahkannya Pancasila sebagai dasar pedoman negara Indonesia, meskipun secara tersirat. Baik yang menyangkut mengenai hubungan manusia dengan Tuhan Yang Maha Esa, maupun hubungan manusia dengan manusia. Hal ini terkandung dalam nilai-nilai yang terkandung dalam sila-sila yang terdapat pada pancasila. Dalam UndangUndang No. 39 tahun 1999 tentang Hah Asasi Manusia, pengaturan mengenai Hak Asasi Manusia ditentukan dengan berpedoman pada deklarasi Hak Asasi Manusia Perserikatan Bangsa Bangsa. Konvensi Perserikatan Bangsa Bangsa tentang penghapusan segala bentuk diskriminasi terhadap wanita, konvensi Perserikatan Bangsa Bangsa tentang hak-hak anak dan berbagai instrumen internasional lain yang mengatur mengenai Hak Asasi Manusia. Materi Undang- Undang ini tentu saja harus disesuaikan dengan kebutuhan hukum masyarakat dan pembangunan hukum nasional yang berdasarkan pancasila dan Undang- Undang Dasar 1945 (Supriyanto, 2014: 156).

Memperhatikan hukum positif suatu negara, tidak dapat dilepaskan dengan sistem hukum yang berlaku di negara tersebut. Karena itu, dasar negara Pancasila yang terdiri atas lima sila, yaitu ketuhanan Yang Maha Esa, kemanusiaan yang adil dan beradab, persatuan Indonesia, kerakyatan yang dipimpin oleh hikmat kebijaksanaan dalam permusyawaratan/perwakilan, dan keadilan sosial bagi seluruh rakyat Indonesia. Ditambah Pembukaan UUD 1945, terutama alenia pertama yang menyatakan: "Kemerdekaan ialah hak segala bangsa serta penjajahan harus dihapuskan", serta alenia kedua "kemerdekan negara menghantarkan rakyatrakyat merdeka, bersatu, adil, dan makmur", mengindikasikan Indonesia adalah negara demokrasi, menjunjung tinggi supremasi hukum, serta menghormati/menjunjung tinggi hak asasi manusia. Apa yang digariskan di dalam Pembukaan UUD 1945 merupakan arah dan politik hukum dalam tatanan makro, kemudian diformalkan dalam bentuk peraturan perundangan oleh lembaga politik/DPR dan dioperasionalkan/dilaksanakan oleh pejabat/aparat negara dalam 
bentuk peraturan pemerintah dan peraturan lainnya sebagai pegangan para birokrat (Efendi, 2014: 155-156).

Karena itu, dasar negara yang tertuang di dalam Pembukaan UUD 1945 yang keputusan dan pilihan bapak-bapak pendiri negara (the founding father), wajib menjadi pegangan setiap pemerintahan di dalam mengisi kemerdekaan, khususnya yang terkait dengan hak asasi manusia. Hal itu terbukti dengan pengakuan beberapa hak mendasar tersebut dalam UUD 1945 yang menjadi landasan konstitusional berdirinya Negara Kesatuan Republik Indonesia, meski UUD itu disusun dalam waktu yang singkat, dari tanggal 29 Mei sampai dengan 16 Juli (Pide, 1999: 63). Hakhak tersebut diantaranya adalah hak atas kedudukan yang sama di depan hukum dan pemerintah, hak untuk menganut agama dan menjalankan ajaran agama/kepercayaannya, hak untuk mengemukakan pendapat, hak untuk berserikat dan berkumpul, hak untuk mendapatkan pendidikan dan pekerjaan yang layak, dan lain-lain. Di situlah jantung dan nafas perjuangan bangsa, disitulah politik hukum dan pilihan hukum yang tidak dapat ditawar-tawar oleh siapa pun dan pemerintah dari kelompok/partai manapun juga, yaitu membangun demokrasi dan penegakan hukum, vinito (Efendi, 2014: 156).

Sila pertama dari Pancasila adalah "Ketuhanan Yang Maha Esa". Konsekuensi lebih lanjut ialah bagaimana kalau ada warga negara Indonesia yang atheis (tiidak percaya kkepada Tuhan). Pada sila pertama ada kesan "memaksa" bahwa warga negara harus ber-Tuhan. Pemaksaan kepercayaan dikesankan bertentangan dengan prinsip kebebasan beragama dalam konsep HAM, termasuk aliran sempalan dari mainstream agama tertentu, Islam misalnya terhadap Ahmadiyah (Efendi, 2014: 156). Undang- Undang Dasar 1945 (yang telah diamandemen), masalah mengenai Hak Asasi Manusia dicantumkan secara khusus dalam bab XA pasal 28A sampai dengan 28J yang merupakan hasil amandemen kedua tahun 2000. Pemerintah dalam hal untuk melaksanakan amanah yang telah diamanatkan melalui TAP MPR tersebut di atas, di bentuklah Undang- Undang No. 39 tahun 1999 tentang Hak Asasi Manusia, pada tanggal 23 September 1999 telah disahkan Undang- Undang No. 39 tahun 1999 tentang Hak Asasi Manusia yang mengatur beberapa hal penting yang menyangkut Pengadilan Hak Asasi Manusia (Efendi, 2014: 156).

Pertama, definisi pelanggaran Hak Asasi Manusia dideskripsikan sebagai setiap perbuatan seseorang atau kelompok orang termasuk aparat negara baik disengaja maupun tidak disengaja atau kelalaian yang secara melawan hukum mengurangi, menghalangi, membatasi dan atau mencabut Hak Asasi Manusia seseorang atau kelompok orang yang dijamin oleh Undang- Undang ini, dan tidak mendapatkan atau di khawatirkan tidak akan memperoleh penyelesaian hukum yang adil dan benar, berdasarkan mekanisme hukum yang berlaku (pasal 1 ayat 6) (Efendi, 2014: 156). 
Kedua, hak untuk hidup, hak untuk tidak dipaksa, hak kebebasan pribadi, pikiran dan hati nurani, hak beragama, hak untuk tidak diperbudak, hak untuk diakui sebagai pribadi dan persamaan untuk tidak dituntut atas dasar hukum yang berlaku surut dapat di kecualikan dalam hal pelanggaran berat terhadap hak asasi manusia yang digolongkan ke dalam kejahatan terhadap kemanusiaan (Efendi, 2014: 156).

Ketiga, dalam Pasal 7 dinyatakan, bahwa setiap orang berhak untuk menggunakan semua upaya hukum nasional dan forum internasional atas semua pelanggaran hak asasi manusia yang di jamin oleh hukum Indonesia oleh negara Republik Indonesia menyangkut Hak Asasi Manusia menjadi hukum nasional (Efendi, 2014: 156).

Keempat, di dalam Pasal 104 diatur tentang pengadilan Hak Asasi Manusia sebagai berikut : Untuk mengadili pelanggaran Hak Asasi Manusia yang berat di bentuk pengadilan dalam ayat (1) di bentuk dengan Undang- Undang dalam jangka waktu paling lama 4 tahun sebelum terbentuk pengadilan Hak Asasi Manusia sebagai mana dimaksudkan dalam ayat (2) di adili oleh pengadilan yang berwenang. Selanjutnya Pasal 104 ayat (1) Undang- Undang No. 39 tahun 1999 tentang Hak Asasi Manusia menyatakan bahwa yang berwenang mengadili pelanggaran Hak Asasi Manusia yang berat adalah pengadilan Hak Asasi Manusia. Pada tanggal 8 Oktober 1999 ditetapkan Peraturan Pemerintah Pengganti Undang-Undang (Perpu) No. 1 tahun 1999 tentang pengadilan Hak Asasi Manusia yang bertugas menyelesaikan perkara pelanggaran Hak Asasi Manusia yang berat. Namun Peraturan Pemerintah Pengganti Undang-Undang No. 1 Tahun 1999 tentang pengadilan hak asasi manusia yang dinilai tidak memadai, sehingga tidak disetujui oleh Dewan Perwakilan Rakyat Republik Indonesia menjadi Undang-Undang dan oleh karena itu Peraturan Pemerintah Pengganti Undang-Undang tersebut di cabut (Efendi, 2014: 156).

Kejahatan terhadap kemanusiaan yaitu perbuatan yang dilaksanakan sebagai bagian dari serangan yang meluas ataupun sistematik yang diketahuinya bahwa akibat serangan itu ditujukan secara langsung terhadap penduduk sipil, berupa pembunuhan, pemusnahan, pembudakan, pengusiran atau pemindahan penduduk secara paksa, perampasan kemerdekaan atau kebebasan fisik secara sewenangwenang, penyiksaan, pemerkosaan, perbudakan seksual, pelacuran secara paksa, pemaksaan kehamilan, sterilisasi paksa, atau bentuk-bentuk kekerasan seksual lain yang setara, penganiayaan terhadap kelompok tertentu atau perkumpulan yang didasari persamaan paham politik, ras, kebangsaan, etnis, budaya, agama, jenis kelamin maupun alasan lain yang telah diakui secara Universal sebagai hal yang dilarang oleh hukum internasional, penghilangan orang secara paksa dan kejahatan apartheid. Dari berbagai kasus pelanggaran Hak Asasi Manusia berat yang terjadi telah mendorong munculnya suatu usulan untuk membantu pengadilan Hak Asasi Manusia ad hoc untuk kasus-kasus pelanggaran Hak Asasi Manusia berat di Aceh. Permintaan Dewan Perwakilan Rakyat mengajukan usulan kepada Presiden 
Republik Indonesia untuk membentuk pengadilan Hak Asasi Manusia ad hoc telah disampaikan oleh Menteri Kehakiman dan Hak Asasi Manusia (Efendi, 2014: 156157).

\section{a. Contoh Kasus:}

Nenek Minah yang berusia 55 tahun tak pernah menyangka perbuatan isengnya memetik 3 buah kakao di perkebunan milik PT Rumpun Sari Antan (RSA) akan menjadikannya sebagai pesakitan di ruang pengadilan. Kejadian ini berawal saat Minah sedang memanen kedelai di lahan garapannya di Dusun Sidoarjo, Desa Darmakradenan, Kecamatan Ajibarang, Banyumas, Jawa Tengah. Lahan garapan Minah ini juga dikelola oleh PT RSA untuk menanam kakao. Ketika sedang asik memanen kedelai, mata tua Minah tertuju pada 3 buah kakao yang sudah ranum. Dari sekadar memandang, Minah kemudian memetiknya untuk disemai sebagai bibit di tanah garapannya. Setelah dipetik, 3 buah kakao itu tidak disembunyikan melainkan digeletakkan begitu saja di bawah pohon kakao. Dan tak lama berselang, lewat seorang mandor perkebunan kakao PT RSA. Mandor itu pun bertanya, siapa yang memetik buah kakao itu. Dengan polos, Minah mengaku hal itu perbuatannya. Minah pun diceramahi bahwa tindakan itu tidak boleh dilakukan karena sama saja mencuri. Sadar perbuatannya salah, Minah meminta maaf pada sang mandor dan berjanji tidak akan melakukannya lagi. 3 Buah kakao yang dipetiknya pun dia serahkan kepada mandor tersebut. Minah berpikir semua beres dan dia kembali bekerja. Namun dugaannya meleset. Peristiwa kecil itu ternyata berbuntut panjang. Sebab seminggu kemudian dia mendapat panggilan pemeriksaan dari polisi. Proses hukum terus berlanjut sampai akhirnya dia harus duduk sebagai seorang terdakwa kasus pencuri di Pengadilan Negeri (PN) Purwokerto.

\section{b. Daftar Putusan}

Minah dijerat Pasal 362 Kitab Undang-undang Hukum Pidana dengan ancaman hukuman enam bulan penjara. Hakim memfonis hukuman 1 bulan 15 hari dengan masa percobaan selama 3 bulan. Vonis yang dihadapi Minah tak sebanding dengan harga kakao yang konon dicurinya. Harga satu kilogram kakao basah saat ini sekitar Rp7.500. "Itu kalau biji kakao telah dikerok dari buahnya," kata Amanah (70), kakak Minah. Menurut dia, dari tiga butir buah kakao hanya menghasilka tiga ons biji kakao basah. "Jika dijual, harganya sekitar Rp2.000," katanya. Akan tetapi dalam dakwaan yang ditujukan kepada Minah, jumlah kerugiannya mencapai Rp30 ribu atau Rp10 ribu per butir. Dia mengaku heran terhadap dakwaan yang ditujukan kepada adiknya karena selama ini dalam pemberitaan di televisi, banyak pelaku tindak pidana korupsi yang menggerogoti keuangan negara ratusan juta hingga miliaran rupiah, hanya dituntut hukuman maupun vonis yang ringan. 


\section{KESIMPULAN}

Hukum progresif merupakan konsepsi yang menjalankan hukum tidak sekedar menurut perundang-undangan, tetapi alat untuk menjabarkan dasar kemanusiaan yang berfungsi memberikan keadilan kepada dunia dan manusia. Asumsi yang mendasari progresifisme hukum adalah pertama, hukum ada untuk manusia dan tidak untuk dirinya sendiri, kedua hukum selalu berada pada status law in the making dan tidak bersifat final, ketiga hukum adalah institusi yang bermoral kemanusiaan. Ide utama dari hukum progresif adalah membebaskan manusia dari belenggu hukum. Menurut hukum progresif, hukum berfungsi memberi panduan bukan justru membelenggu, manusia-manusialah yang lebih penting dan tidak terpaku pada peraturan perundang-undangan yang ada. Sedangakan menurut hukum positif, norma hukum yang ditetapkan itu tidak lain adalah Undang-undang, dan teori hukum positif mengakui adanya norma hukum yang bertentangan dengan nilai moral. Negara Indonesia dalam menghormati, melindungi, dan memajukan HAM bagi warganegaranya, kemudian disahkan sejumlah UU seperti: UU No. 8/1999 tentang Kebebasan Menyatakan Pendapat; UU No. 39/1999 tentang HAM;UU No. 26/2000 tentang Pengadilan HAM; Amandemen berbagai UU untuk diselaraskan dengan prinsip-prinsip HAM, seperti UU Parpol, UU Kekuasaan Kehakiman, pencabutan Penpres No. 11/1963, dsb. Dan diiluncurkannya Rencana Aksi Nasional HAM (RAN-HAM) dalam rangka memberikan jaminan bagi peningkatan pemajuan dan perlindungan HAM di Indonesia dengan mempertimbangkan nilai-nilai adat istiadat, budaya, dan agama bangsa Indonesia yang berdasarkan Pancasila dan UUD Tahun 1945. 


\section{DAFTAR PUSTAKA}

Adji, Oemar Seno. 1984. KUHAP Sekarang. Jakarta: Penerbit Erlangga.

Atmasasmita, Romli. 2012. Teori Hukum Integratif. Yogyakarta: Genta Publishing.

Efendi, Mahsyur dan S. Evandri, Taufani. 2014. HAM dalam Dinamika/Dimensi Hukum, Politik, Ekonomi, dan Sosial. Bogor: Ghalia Indonesia.

Erwin, Muhamad. 2012. Filsafat Hukum. Jakarta: Rajawali Pers.

Esmi, Warassih P. 2005. Lembaga Prana Hukum Sebuah Telaah Sosiologis. Semarang: Suryandaru Utama.

F.S., Anton. 2004. Wajah Peradilan Kita Kontriksi Sosial Tentang Penyimpangan Mekanisme Kontrol dan Akuntanilitas Peradilan Pidana. Bandung: PT. Refika Aditama.

Harahap, M. Yahya. 2000. Pembahasan Permasalahan dan Penerapan KUHAP Penyidikan dan Penuntutan. Jakarta: Sinar Grafika.

Ibrahim, Anis.. 2010. Telaah Yuridis Perkembangan Hukum Positif tentang Hak Asasi Manusia (HAM) di Indonesia. Lumajang: Jurnal Hukum Argumentum. Vol. 9, No. 2. hlm. 1-13.

Lisanawati, Go. 2014. "Pendidikan Tentang Pencegahan Kekerasan Terhadap Perempuan dalam Dimensi Kejahatan Siber". Jurnal Ilmu Hukum Pandecta Vol. 9 No.1, hlm 1-17

Muhammad, Rusli. 2006. "Kajian Kritis Terhadap Teori Hukum Positif (Positifisme)". Jurnal Hukum Republica Vol. 5, No. 2, hlm. 220-234

Mujahidin, Ahmad, 2007, Peradilan Satu Atap di Indonesia, Bandung: Refika Aditama. Nusantara, Abdul Hakim G. 2004. "Sebuah Upaya Memutus Impunitas: Tanggung Jawab Komando Dalam Pelanggaran Berat Hak Asasi Manusia”. Jurnal HAM. Vol 2. No. 2 November 2004.

Prince Zeid Ra'ad, Al Hussein. 2017. Klatsky Endowed Lecture, Presented by the U.N. High Commissioner for Human Rights. International Law: Case Western Reserve Journal.

Rahardjo, Satjipto. 2006. Membedah Hukum Progresif. Jakarta: Kompas.

Rahardjo, Satjipto. 2009. (dalam I Gede A.B.Wiranata, Hukum Bangun Teori dan Telaah dalam Impelementasinya).

Rukmini, Mien. 2007. Perlindungan HAM melalui asas praduga tak bersalah dan asas persamaan kedudukandalam hukum dalam sistem peradilan pidana Indonesia. Bandung: PT Alumni.

Sarmadi, A. Sukris. 2012. "Membebaskan Positivisme Hukum Ke Ranah Hukum Progresif”. Jurnal Dinamika Hukum. Vol.12, No.2, Tahun 2012. 
Siahaan, Lintong O. 2006. "Peran Hakim Dalam Pembaharuan Hukum di Indonesia". Jumal Hukum dan Pembangunan, Tahun ke 36 No.1 Januari 2006, Jakarta: Fakultas Hukum Universitas Indonesia.

Supriyanto, Bambang Heri. 2014. "Penegakan Hukum Mengenai Hak Asasi Manusia (HAM) Menurut Hukum Positif di Indonesia". Jurnal AL-AZHAR INDONESIA SERI PRANATA SOSIAL, Vol . 2, No. 3, Maret 2014

Tanya, Benard L.. 2010, Teori Hukum Strategi Tertib Manusia Lintas Ruang dan Generasi. Yogyakarta: Genta Publishing.

Utsman, Sabian. 2008. Menuju Penegakan Hukum Responsif. Ctk.pertama, Yogyakarta: Pustaka Pelajar. 